\title{
European Union Support in the Improvement of Quality Management Systems in Administration Offices in Poland
}

\author{
Urszula Kobylińska
}

Bialystok University of Technology

O. Tarasiuka Str. 2, PL 16-001 Kleosin/Białystok

cross $\mathrm{http} / / / \mathrm{dx}$. doi.org/10.5755/j01.ppaa.15.1.14690

\begin{abstract}
In many countries of Europe and the world, in the past several years, management in the public sector has been radically changed. The experience of the administration of each country shows that organizations in this area have a significant impact on the economies, taking over increasingly more responsibilities in solving many complex socio-economic problems. In order for the task of public entities to be effectively executed and correspond to social expectations, it becomes necessary to implement structures of management tools, in particularly, quality standards. Implementation of practical solutions in the field of quality management results in the establishment of corporate standards, more efficient use of resources and greater citizen satisfaction with the work of public institutions.

Quality management systems have become the standard in public administration offices in Poland. The most common tool in this area is ISO 9001. Some offices choose to improve the quality of services with the use of the CAF self-assessment. Many authorities improve their services by utilising project financing from the European Union funds. This paper analyzes the effectiveness, relevance and sustainability of the implementation of quality management tools in local government units in Poland.
\end{abstract}

Keywords: quality management system, ISO 9001, Common Assessment Framework (CAF), improving quality system.

Raktažodžiai: kokybès valdymo sistema, ISO 9001, bendrasis vertinimo modelis (BVM), kokybès sistemos gerinimas.

\section{Introduction}

Several changes are currently taking place in the public sector, as greater emphasis is being placed on methods and practices aimed at raising the functional level of the public services. The focus is on performance, through output measurements, efficient use of resources, through small, flat and lean organizational 
structures and introduction of market-style mechanisms through personnel development, training and rewards [5]. One of the modern management methods used by public administrations in the last decade of the 20th century is the quality management. For almost 15 years in Poland, central and local government authorities have been introducing quality management systems. The most popular tool in this area is the ISO 9001 standard. Among other quality management tools used in the national administration one can mention CAF systems to monitor customer satisfaction. The practice of implementing the first innovation in the area of quality management to offices was not only linked for novelty value, but entailed more important applications. Public opinion in Poland has objections to the performance of authorities and their negative image. Increasing expectations and demands of citizens at government offices resulted in the growth of public awareness of the role of citizens in relation to central or local government. After the Polish accession to the $\mathrm{EU}$, requirements for public management methods increased dramatically. Authorities had to adapt their structure to European standards, becoming more flexible and open to customer.

In recent years in Poland, the number of EU programs targeted at improving the quality of central and local administrations has increased. The main aim is to improve the quality of public services provided by offices and to enhance policies and programs at regional and local levels. Projects are mainly aimed at strengthening the capacity of Polish administration to carry out its functions in a modern and interactive way, including, through the implementation of management models and methods. It is expected that in the course of their implementation the efficiency and effectiveness of performance of government entities will increase.

It has been a few years since the theoretic assumptions of quality management have been verified by practical implementation of management tools for local administration offices, as part of projects funded by the Facility 5.2.1. Modernization of management in local government, the Human Capital 2007-2013. The tasks were related to the modernization of the management processes and implementation of improvements to the units of local administration. A significant part of these projects are related to the implementation of specific management tools to institutions of selfgovernment, including implementation of quality management systems according to ISO 9001, CAF model or monitoring of customer satisfaction level.

The purpose of this article is to present quality management tools used by the offices of local administration in Poland that have benefited from projects funded under the Facility 5.2.1. The author analyzes the effectiveness, relevance and sustainability of the implementation of quality management tools in local government units in Poland.

\section{Quality management tools in self-government administration}

Quality management holds a number of features: the objective is to gain customer satisfaction; quality is defined by the customer; it affects all activities of the organization, directly or indirectly related with the product or the service; customers 
are external; it closes the activities of control, but primarily entails the management of the entire organization; everyone is engaged in its application; participation is determined by commitment; methodology is particularly directed toward prevention; it aims to do the right things "from the beginning"; the responsibility and the involvement of everyone from the organization [10].

Quality management concepts and tools are to be categorized, analyzed and further developed to disseminate their use at provincial and municipal levels as well as in various public institutions. Research is focused on ISO 9001 systems and selfassessment, based on the CAF standard. The quality management system that complies with the ISO 9001 standard has already been implemented in a large number of different types of local governments in Poland (municipal/city offices, district offices, Marshals' offices). The main intention of the ISO 9001 standard was "ensuring an orderly and systematic quality of products and services" [17]. As noted by P. Jedynak, the primary role of the quality management system conforming to ISO 9001 involves formalization, which is a result of its introduction [4]. R. Karaszewski added that the implementation of the quality management system requires more than just creating quality assurance procedures. He pointed out, for example, the need for a culture of quality in the organization [7]. Claimed benefits of ISO in the public sector also include more rigorous systems and operational measurement, while critics argue that increased bureaucracy and decreased flexibility are harmful effects resulting from ISO [6].

The quality management model proposed in ISO 9001 has been found suitable for many types of organizations, including local government institutions. ISO 9001 requires the authority office to adapt to its requirements, starting with the identification of customer requirements, through all the processes of the quality management until obtaining customer satisfaction. The content of requirements included in sections of the standard provides the organization flexibility in their implementation. Organization, taking into account its own potential and needs, decides on the ways of implementation of these criteria (e.g. how many procedures it will develop, how often management review will be conducted) [1]. The model of formalized quality management in administration office (Fig. 1) indicates the relationship between four main requirements included in chapter titles of the standards that regard:

- responsibility of management - (including the establishment of policy and quality objectives, adequate leadership),

- resources management - (including provision of appropriate qualification of employees, training policy, working environment, information flows);

- process management - (including areas of customer service, provision of administrative services),

- measurement, analysis and improvement - (including customer satisfaction measurement, auditing, process control, supervision of non-compliances).

Authority offices that have implemented formal quality management systems are obliged by the standard to take measures aimed at increasing the effectiveness and 
efficiency of the system. Improvement of the quality management system is carried out on the recommendations included in ISO 9001, for example, effective implementation of the quality policy, establishing measurable quality objectives, training employees, conducting internal audits, management reviews, corrective and preventive actions.

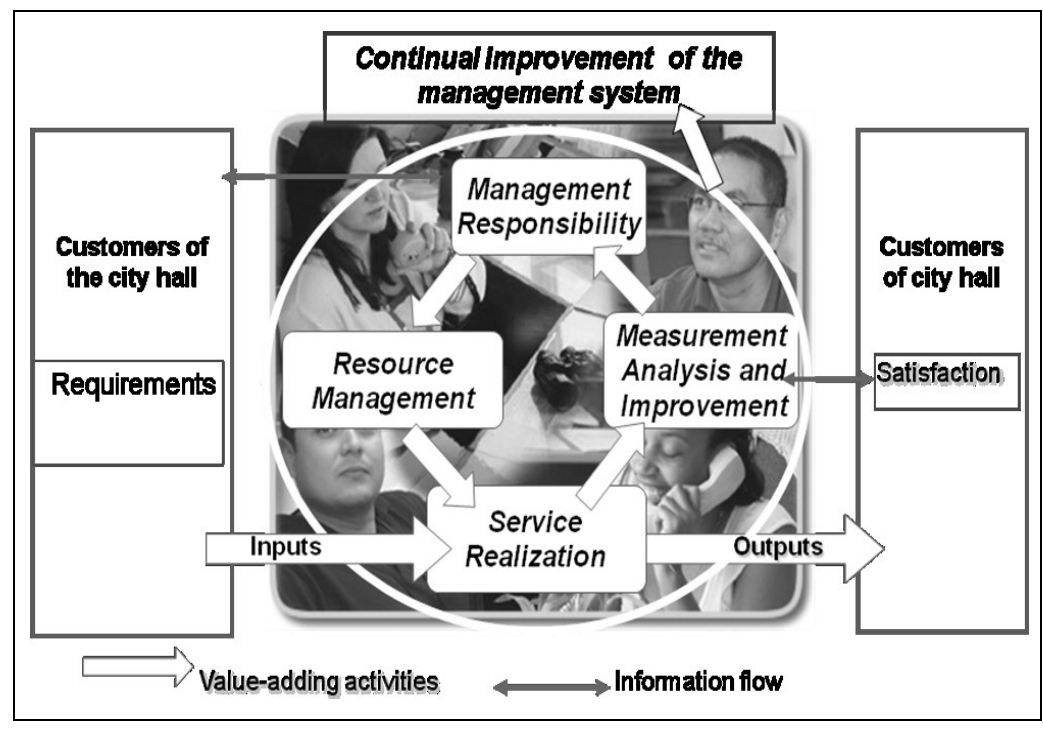

Figure 1. Model of formalized quality management in administration office

Source: created by the author based on [14]

In view of the implementation of the quality management system compliant with ISO 9001, there is also criticism. The wave of criticism concerns the high level of bureaucracy, rigidity of the system that does not adequately support creativity and directs greater emphasis to achieving compliance with the requirements, rather than to continuous improvement of quality [11]. Despite these drawbacks, the concept of quality management according to the requirements of ISO 9001 standard in Poland is still a leading strategy in the field of quality management in local government units. This solution is useful for public organizations because it brings order to the processes and the documentation thereof, provides repeatable actions and, what is very important, results in the creation of a positive image of the organization with customers.

Another way of modernizing the management of self-government institutions and improving the quality of their services is the implementation of the CAF (Common Assessment Framework). It allows initiating a process of continuous improvement of public institutions. It is a modern tool for total quality management targeted at public organizations. The model is an attempt to create a versatile instrument for assessing the quality of management in public administration of the $\mathrm{EU}$ - it is used to compare the performance of entities operating in different 
administrative systems [20].

The CAF model helps organizations of public administration in EU countries to understand and use quality management techniques and diagnose the condition of the management system. It may prove be the right tool to be used by managers in the office with ISO 9001 in the review of governance, enabling the organization to gain a strong base to begin the process of continuous improvement of the quality management system. An additional advantage of the presented self-assessment is the ease of application, the involvement of small resources and short-term of implementation. One of the goals of the CAF is to promote peer review and bench learning within the European public administration [19].

$\mathrm{CAF}$ is one of the tools of public administration management of a systematic character. It can be used in any unit of public administration, because its principles are sufficiently general and can be implemented independent of the structure, size or specifics of the office. It is useful for both those offices that have already started work on quality, and, for example, were awarded ISO certificates, as well as those that are just looking for their own path of improvements; in the latter, the CAF can be treated as zero audit. Offices after obtaining ISO certification sometimes have some difficulty in determining the next steps "after certification." CAF diagnose strengths and weaknesses of the office management and facilitates the selection of improvement activities [2].

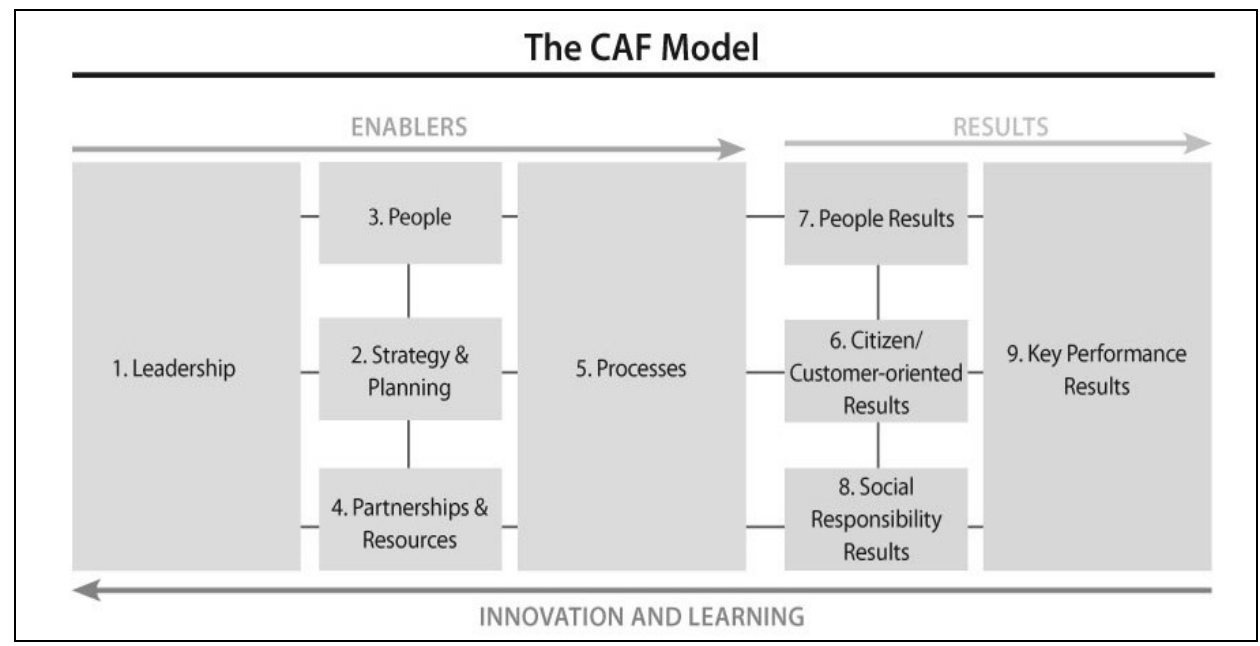

Figure 2. CAF model

Source: [3]

CAF structure includes 9 categories divided into two groups: the "Potential" and "Results" (Fig. 2). Categories of potential allow for description of the way in which the organization carries out its key functions and how it comes to achieving the desired results, and the categories of results relate to the results achieved by the organization in all aspects of its activities. A list of criteria is determined for each of 
these areas. The criteria relate to basic issues to be considered when assessing the organization. The structure of the CAF model is based on the EFQM Excellence Model - a tool for measuring the progress of improvement of the organization, including the public councils. EFQM methodology allows for an objective and reproducible scoring and an indication of their level of management to other European offices. The use of the EFQM model for administrative offices can be done on several levels, starting at a minimum, which is used to review the status of the organization and planning of improvement activities, and ending with a full approach that allows the acquisition of the European Quality Award winners [7].

The condition for the efficacy of the model application is proper implementation of improvement activities. On one hand, compliance of implementation with the plan and schedule needs to be ensured, on the other hand inspections need to be done in order to correct, add or develop the initial assumptions. After the implementation of the improvement actions, evaluation should be informed regarding implementation efficiency and, above all, in terms of benefits and the impact on the performance of the organization. Conducting self-assessment process and improvement is not a onetime project, but it should be repeated periodically. Only then the organization has a chance to reach higher levels towards organizational excellence.

The model of ISO 9001 is a more popular option than the CAF, because its reach is global. The CAF is used only in EU countries. The percentage of CAF implementation in the administrations of the EU, however, does not exceed 35\% [7].

Poland is the third largest in Europe (after Italy and Belgium) by the number of registered CAF users. The database maintained by the European Institute of Public Administration (EIPA) has 279 registered organizations, and a total of 2382 subjects are Polish [20]. However, both models - the CAF and ISO 9001 - should not be compared as "better or worse". If they point to the advantages and disadvantages of these quality management tools, they can be summarized in the three points (Table 1).

Specific beneficial outputs ISO 9001 can deliver in the public services:

- greater emphasis on leadership, communications and change management;

- improved efficiency and service quality;

- continual improvement and customer focus;

- promotion and standardisation of good working practices with control of key processes;

- $\quad$ aid to staff mobility through defined and documented operating procedures.

The CAF model, similarly to the quality management system, complies with the requirements of ISO 9001 and includes concepts of improving the quality of the organization work that complement each other, providing authorities of the offices with many tools that can be used to improve the quality level. Both instruments are based on the universal principles of management and they should be used in a complementary manner. The CAF in relation to the ISO 9001 standard can be used:

- as a method of improving the quality management system according to ISO 9001 - elements of CAF can be used in determining activities that improve the quality management system; 
- for preparing information for management review by the managers of the office which has ISO 9001;

- $\quad$ as a method of preparing for the implementation of a quality management system according to ISO 9001.

\section{Table 1. Advantages and disadvantages using CAF and ISO 9001}

\begin{tabular}{|c|c|c|}
\hline & Disadvantages & Advantages \\
\hline \multicolumn{3}{|c|}{ ISO 9001} \\
\hline 1. & $\begin{array}{l}\text { Requirements included in the standard, } \\
\text { which, if not followed, could lose } \\
\text { certification }\end{array}$ & External certification \\
\hline 2. & $\begin{array}{l}\text { Large number of documents needed for the } \\
\text { implementation in the organization }\end{array}$ & $\begin{array}{lll}\begin{array}{l}\text { Streamlining and } \\
\text { documentation }\end{array} & \text { standardization of } \\
\end{array}$ \\
\hline 3. & $\begin{array}{l}\text { The need to impose additional obligations } \\
\text { on officials associated with the audit and } \\
\text { inspection of ISO } 9001\end{array}$ & $\begin{array}{l}\text { Internal and external customer satisfaction } \\
\text { survey }\end{array}$ \\
\hline \multicolumn{3}{|c|}{ CAF } \\
\hline 1. & $\begin{array}{l}\text { This requires a system, which is not always } \\
\text { observed }\end{array}$ & Requires no certification \\
\hline 2. & Confusing vocabulary model & $\begin{array}{l}\text { The organization itself dictates the } \\
\text { requirements for improvements }\end{array}$ \\
\hline 3. & Voluntary model & $\begin{array}{l}\text { Allows employees to gather opinions on } \\
\text { how to manage }\end{array}$ \\
\hline
\end{tabular}

Source: created by the author

A good opportunity for self-assessment with the CAF model is, in the opinion of P. Rogala, the starting point of the quality management system implementation and a period of one to two years after its implementation. This is, in the author's opinion, the period in which the self-assessment is most effective [17].

\section{Management reform in the public sector in Poland}

The Republic of Poland comprises 16 regions or voivodships (województwo) (Fig. 3), 379 counties (poviat) and 2479 municipalities (gmina) [18]. In total 65 counties out of 379 are urban municipalities with special status of a "city with county (poviat) rights". 235061 were employed in local government administration, with 182079 employees in the state administration in Poland in 2012.the bad intergovernmental, socio-economic and political conditions under which local governments have to function. Since 1989, the changes in the public sector in Poland have had the following trends:

- reactivation of the local government;

- $\quad$ privatization of the public sector;

- administration reform, education and health care reform;

- reduction of the central public sector.

In principle, tasks in the area of administrative structure modernization and ways 
of their functioning were implemented in the forthcoming reforms of public sector decentralization. After 1989, the first step was the introduction of self-government at the municipal level. Then, in 1999, a new administrative division was introduced in Poland. The two-level administrative division in force since 1975 was replaced by a three-level division, which includes województwa (voivodships) powiaty (districts) and gminy (municipalities).

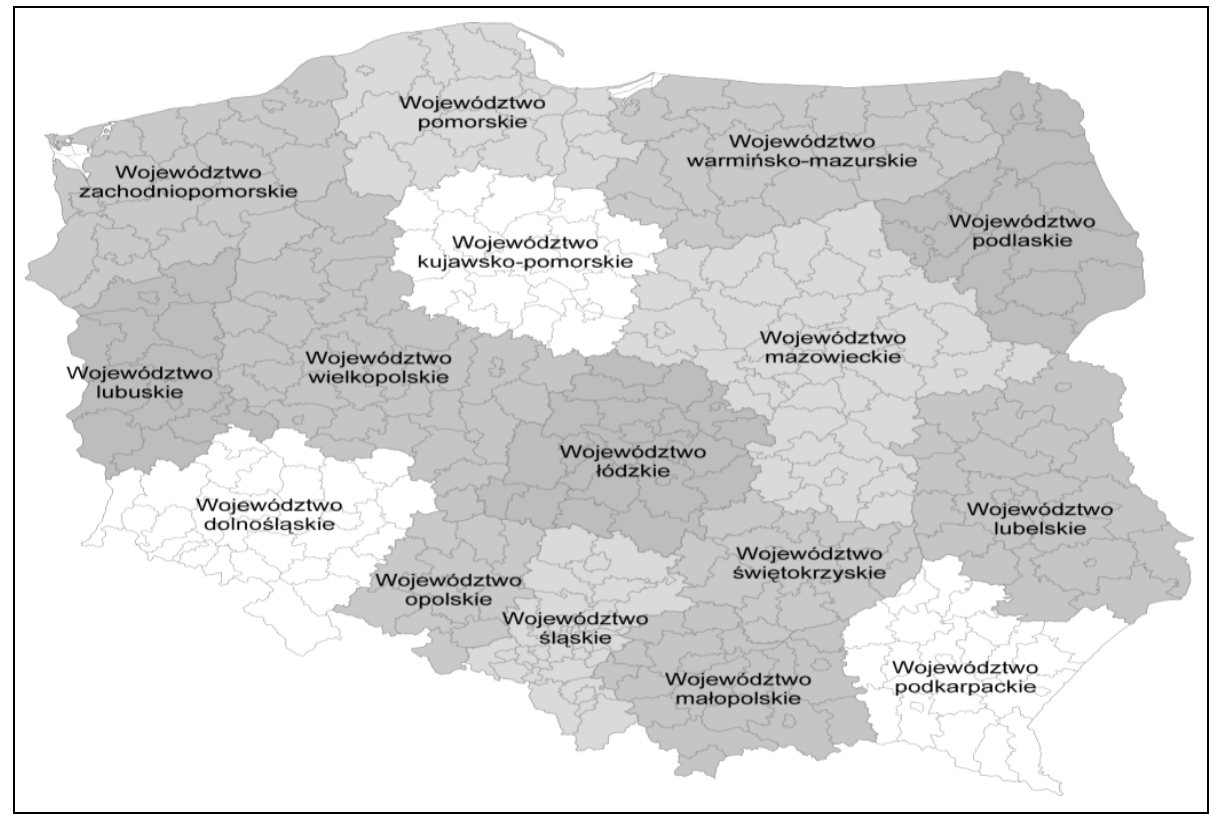

Figure 3. Polish territorial division - 16 voivodships

Source: [15]

The public administration reform in 1999 resulted, among others, in the transfer of about $63 \%$ of the state sector units (out of about 12000 ) to the municipal sector, subordinated to the newly established units of local government [8]. The function of government administration was changed which in its new shape had to focus attention on the priority actions such as the formulation of policy or creation of a development strategy. The municipal sector was to provide public service, in line with the agreed standard. After the administrative reform of 1998 the process of adaptation of modern management methods and tools of public tasks management started.

In mid-June 2000 the Civil Service Office started a program of "Friendly Administration". Its goals were defined by the head officer as follows: "competent, polite, providing comprehensive information officers and friendly public administration offices". The tools and techniques of quality management were used in implementation of the program. On the basis of the first national experiences and exploration of optimal solutions concerning the functioning of administration, the socalled concept of Institutional Development Programme was developed. Its main 
objective was to define the principles of institutional development of public administration units, including an analysis of the level of institutional development, designing institutional changes (improvements) and their implementation. The basic concept of the Programme is based on starting up in offices a continuous improvement process, including the cycle from the office organization evaluation, through planning changes and their implementation, to monitoring of the plan.

In Poland, the implementation concept based on the quality created a large potential for improving innovativeness. This possibility was created by the European Social Fund which financed the activities implemented under the Priority V Good Governance, Human Capital - Facility 5.2. "Strengthening the capacity of local government administration". The projects implemented in its framework were mainly aimed at empowering Polish administration to carry out their functions in a modern and interactive way. A large number of these projects related to the implementation of specific management tools in the institutions of government, including implementation of quality management systems according to ISO 9001, CAF and customer satisfaction monitoring systems [9].

Furthermore, the guidelines of public administration reform in Poland were based on the following assumptions: supporting the development of civil society, the principle of subsidiary, effectiveness in providing public services, transparency of administrative structures and decision-making process [13]. Started in the late 90s, the administration informatisation process was aimed at improving the operation of Polish administration through the use of information and communication tools in dealing with citizens' priorities was also significant.

\section{Quality management in practice in Polish local government units}

Projects of competition under Facility 5.2.1., which form a part of the priority axis V Operational Programme Human Capital - Good governance, carried out in 2007-2013, were aimed at improving the quality of public services provided by the offices at the level of local government and improving the quality of regional and local policies and programs. Actions implemented within the Facility related to modernization of management processes in units of local government.

In 2012 a report was compiled on the evaluation studies of projects under the discussed Facility. From 2008 onwards, under Facility 5.2 modernization support covers over $50 \%$ of all local government units (over 1400 offices in Poland). Over 400 different projects worth more than 700 million PLN were completed. The evaluation study covered 106 projects worth a total amount of 140 million PLN, which ended by 31 March 2012 [12]. The subject of the survey was and is on-going evaluation of projects. The objective of Facility 5.2 is to improve the quality of public services provided by public administration institutions and offices at the level of local government units, and to improve the quality of policies and programmes of regional and local scope. The aim of the survey was to examine and evaluate selected improvements concerning an upgrade of management practices. The improvements were implemented in 659 local government institutions and offices. 
This article focuses mainly on management improvements based on quality management, implemented under Facility 5.2.1 to offices, the recipients of support (municipal offices, district offices, Marshals' offices), because the largest percentage of quality systems in Poland were implemented in districts and cities (Table 2). Results included in the article are based on the evaluation report published in 2012 [12].

Table 2. \% of implementations quality management systems in local government offices in Poland

\begin{tabular}{|l|c|}
\hline \multicolumn{1}{|c|}{ Type of local government in Poland } & $\begin{array}{c}\text { \%o of implementations quality management } \\
\text { (ISO 9001, CAF, other models) }\end{array}$ \\
\hline Rural Municipality & 7,6 \\
\hline Urban Municipality & 38,3 \\
\hline Rural-Urban Municipality & 19,7 \\
\hline Cities (as Poviat/county) & 80 \\
\hline Poviat/County & 27,5 \\
\hline
\end{tabular}

Source: [21]

ISO 9001 under this Facility was implemented in $37 \%$ of offices $(\mathrm{N}=229)$. The same number of offices implemented monitoring of customer satisfaction. These were mostly popular management improvements introduced through participation in the project. Fewer offices implemented website upgrades (15\%), electronic workflow $(12 \%)$ or CAF model $(10 \%)$. E-services were the least frequently implemented improvement - it was observed only in $2 \%$ of offices (Fig. 4 ).

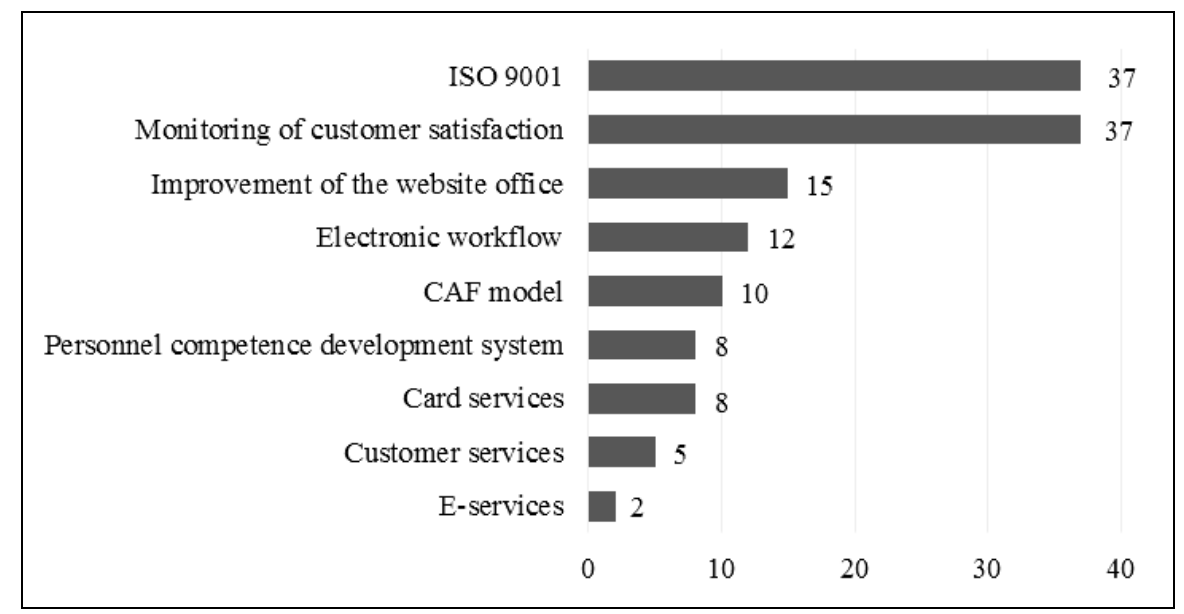

Figure 4. Improvements implemented under the $\mathbf{1 0 6}$ projects in an attempt to support customers in Polish local governments, \% ( $\mathrm{N}=614)$

Source: [12]

Although the majority of entities evaluated with ISO 9001 certificate positively 
assess the impact of the system on their operations, only $67 \%$ of the units are planning to renew the certificate after the expiry date, and only $26 \%$ of respondents strongly believe they will do it, which does not fully confirm trust to the certificate and its effectiveness in regard to the quality of their actions. Positive evaluation of the ISO 9001 functioning in the surveyed offices focuses on dimensions such as the image improvement ( $77 \%$ of respondents), improvement of the overall office functioning (72\%) and improvement of internal communication (66\%).

Every tenth office had complaints about the time-consuming maintenance of the system, and every fifth - about the lack of acceptance by employees. Passive attitudes of staff were very often followed by no commitment of the office management about the benefits of ISO 9001. The results of research into the effectiveness and sustainability of this management system also seem alarming. Only 20\% of respondents noticed a decrease in the number of complaints from customers, and in less than $34 \%$ of the institutions customer service time was shorter and punctuality improved. Implementation of ISO 9001 was not a sufficient stimulus for the implementation of improvement activities, such as implementation of the CAF.

The study authors also noted that the greatest threat to the sustainability of the quality management system was the time. Consequently, there is a noticeable insufficient observance in the projects of the key principle of management responsibility, mainly insufficient involvement in the formation and development of the ISO. In the case of local authorities a major threat to the organization's leadership sustainability is the term of authority office and political conditions - highly probable changes in positions of senior management and the ISO representative in the office. The reasons for non-renewal of the certificate after the expiry of its validity may indicate a lack of a systematic approach to quality management and treating the ISO only as a marketing tool, which may call into question the process of continuous improvement in the office management.

The CAF model was implemented in the framework of projects with the EU support, three times less often by the researched local government units than, e.g. ISO 9001. The units which have implemented the CAF had already implemented the ISO 9001 (more than $40 \%$ of the local government units). In the case of using the CAF by offices, difficulties of the conceptual model, and thus the barrier to the implementation in the offices, was confirmed.

Most respondents in the researched organizations confirmed the development, through the application of the method, some formal effects of this process - more than $90 \%$ of offices developed a self-assessment report, while less often an improvement plan was developed (84\% of offices). Only two-thirds of local governments have undertaken improvement projects identified as a result of selfassessment and a minor number of local governments (only 25\%) made a reevaluation after completion of the project. Repetition of self-assessment by only one in four offices, and over $40 \%$ of offices not repeating it, or with no plans in this regard, call into question the point of using such a method for which the main essence is to implement a permanent system of self-assessment and identify areas for 
improvement. Among offices that have identified areas for improvement and have taken development projects they mostly regarded the changes in the system of human resource management, employee satisfaction surveys or reorganization of office work. Opinions of the examined offices on the advantages of the method CAF are less optimistic than in the case of ISO 9001. Although respondents noted that the application of the method contributed to the overall improvement in the functioning of the office ( $70 \%$ of opinions), and to the improvement of internal communications (66\% reviews), it was rarely translated into an increase in employee satisfaction (only $34 \%$ of respondents indicated an increase of work satisfaction after the implementation of the method) and very rarely they indicated the reduction of operating costs (opinion of only $3 \%$ of offices). The fact that too few offices developed a plan for improvement - in fact, the integral effect of self-assessment, is not optimistic. As indicated by the authors of the evaluation report, offices had insufficient support and leadership of the top management, which is a key component of the efficiency and sustainability in the use of this method. In addition, an insufficient number of training on the CAF and the aforementioned uneasy conceptual apparatus, operated by the method, reduced the potential benefits that could be obtained by the offices as a result of its use.

Implementation of ISO 9001 and the CAF model requirements is not an easy undertaking, and usually requires the assistance of professional consultants. As indicated by a the research results, implementation of such projects without external support would be a problem for most offices, as $40 \%$ of them would not introduce CAF improvements at all and over $43 \%$ of respondents would not implement ISO 9001, if not for external support. For the sustainability of the implemented pro-quality solutions the sceptical approach of respondent offices to renew ISO certification after 3 years of using it also seem dangerous. This involves additional costs for outsourced certification, but also internal costs incurred in the office to maintain that labourintensive system. The situation is similar for the implementation and maintenance of the CAF model. Only $25 \%$ of offices decided to carry out self-assessment after the project ended.

Summarizing the results of the research can inform the following conclusions regarding quality management in local government in Poland:

- ISO 9001 within the framework of the project founded by EU implement $37 \%$ of offices. It was the most popular management improvement made by taking part in the project (mainly in urban cities and medium-sized offices);

- positive assessment of the functioning of ISO 9001 in offices mainly concerns such dimensions as to improve the image (77\% of responses), improving the overall functioning of the office (72\%), improving internal communication (66\%);

- among other positive aspects of the ISO a clear division of responsibilities, elimination of errors in the operation, the ability to control operations by new officials were indicated;

- $20 \%$ of respondents felt that after the implementation of ISO 9001 the 
number of complaints from customers reduced and less than $34 \%$ of the institutions noted shorter time customer service and improved punctuality in matters;

- $70 \%$ members of ISO, noticed its impact on improving the overall performance of the organization and internal communication (66\%). Relatively rarely it translated into an improvement in employee satisfaction (34\%), and occasionally in cost reduction (3\%).

- offices noted that the application of the CAF contributed to the overall improvement in the performance of the office ( $70 \%$ of opinions), and improvement of internal communications (66\% reviews), but it rarely translated into an increase in employee satisfaction (only $34 \%$ of respondents indicated an increase of work satisfaction after the implementation of the method) and very rarely they indicated the reduction of operating costs (opinion of only 3\% of offices). Except that only twothirds of local governments have undertaken improvement projects identified as a result of self-assessment and a minor number of local governments (only 25\%) made a re-evaluation after completion of the project. It can provide low sustainability and usefulness of the CAF.

In terms of sustainability of project effects, it should be emphasised that the key factor is the attitude of decision-makers followed by employee approval and financial capabilities (especially relevant with ISO). Where decision-makers recognised the need to support the implementation, they persisted in activities promoting the implementation and actively participated in these activities. As far as employee acceptance is concerned, it was on the one hand a by-product of decision-makers' attitude (i.e. if superiors are reluctant to implement solutions, employees will also be reluctant), and, on the other hand, an important role was played by the feeling that the solutions were actually useful.

\section{Conclusion}

1. Quality management is an essential strategic factor of success in the public sector. Executives of local politics and government recognise the importance of customer focus and therefore continue to implement quality management systems. Customer focus and quality management are critical factors in optimising demand, supply and costs throughout the public sector.

2. Summing up the considerations made in this article it should be noted that the Polish authority offices entered the path of continuous improvement, largely thanks to the EU projects, which were aimed at supporting the management of Polish local government units. However, sustainability, efficiency and usability of tools that allow for supporting the management and improving the quality of services, such as ISO 9001, CAF, is not always noticeable, in the respondents' opinion.

3. The most popular among management improvements was the ISO 9001 certification. It can be assumed that such an approach can be attributed to the willingness of Polish authorities to represent "culture of compliance" and the 
requirements of the ISO 9001 standard in this area can be considered as such. In addition, in the case of offices the market pressure is not as noticeable as it is in commercial entities, which would oblige them to look for other ways to improve their management systems.

4. The greatest threat to the sustainability of the quality management system in an office in Poland is the passage of time. What's next, consequently, in their projects there is a noticeable insufficient respect for a key principle of management, mainly involved in the creation and development of the ISO. In the case of local sustainability, a major threat to the organization's leadership tenure authorities and political conditions - highly probable changes in positions of senior management and the ISO representative office. The reasons for non-renewal certificate after the expiry of its validity may indicate a lack of a systematic approach to quality management and ISO treatment as only a marketing tool, which may call into question the process of continuous improvement in the management office.

\section{References}

1. Borys, T., Rogala, P. Systemy zarzadzania jakościq i środowiskiem. Wrocław: Uniwersytetu Ekonomicznego we Wrocławiu, 2007.

2. Czaputowicz, J. Wspólna Metoda Oceny Administracji Publicznej w państwach Unii Europejskiej. Stużba Cywilna, 2002.

3. European Institute of Public Administration (EIPA). Available at: http://www.eipa.eu/ [2015-04-18].

4. Jedynak, P. Ocena znormalizowanych systemów zarządzania jakością. Kraków: Uniwersytetu Jagiellońskiego, 2007.

5. Kakouris, A. P., Meliou, E. New Public Management: Promote the Public Sector Modernization through Services Quality. Current Experiences and Future Challenges. Public Organization Review, 2011, Vol. 11, p. 351-352.

6. Karaszewski, R. Systemy zarządzania jakościa największych korporacji świata i ich dyfuzja (zjawisko, rozwój, znaczenie). Toruń: UMK, 2003.

7. Kobylińska, U. Modele oceny jakości administracji. Białystok: WSAP, 2010.

8. Kobylińska, U. Orientacja na jakość w administracji publicznej. Administracja Publiczna, 2013, Vol. 2, p. 64-75.

9. Kobylińska, U. Rozwój systemów jakości w administracji publicznej. Marketing $i$ Rynek, 2014, Vol. 5, p. 808-814.

10. Matei, L., Lazar, C. G. Quality Management and the Reform of Public Administration in Several Statesin South-Eastern Europe. Comparative Analysis. Theoretical and Applied Economics, 2011, Vol. 18, No. 4, p. 65-98.

11. McAdam, R., Reid, R., Saulters, R. Sustaining Quality in the UK Public Sector. Quality Measurement Frameworks. International Journal of Quality \& Reliability Management, 2002, Vol. 19, No. 5, p. 581-595.

12. Ministerstwa Administracji i Cyfryzacji. Jak doskonala się samorzady? Ewaluacja pn. „Ocena projektów konkursowych zrealizowanych $w$ ramach poddziałania 5.2.1. Modernizacja zarządzania w administracji samorzadowej PO KL 2007-2013”, 2012. 
Available at: http://docplayer.pl/698575-Jak-doskonala-sie-samorzady.html [2015-0204].

13. Ministerstwa Administracji i Cyfryzacji. System administracji publicznej w Polsce, 2014. Available at: https://mac.gov.pl/files/administracja_prezentacja.pdf.

14. PN-EN ISO 9001: 2009. System zarzadzania jakościa. Wymagania, Warszawa: PKN, 2009.

15. Polish territorial division. 16 voivodships, 2015. Available at: http://biznespolska.info/firmy/woj.gif.

16. Quazi, H. A., Hong, Ch. W., Meng, Ch. T. Impact of ISO 9000 Certification on Quality Management Practices: A Comparative Study. Total Quality Management, 2002, Vol. 13, No. 1, p. 53-67.

17. Rogala, P. Podstawowe narzędzia zarządzania jakością w jednostce samorządu terytorialnego. Problemy Jakości, 2002, Vol. 4, p. 12-15.

18. Samorząd terytorialny $\mathrm{w}$ Polsce. Baza JST Administracja, 2015. Available at: https://administracja.mac.gov.pl/adm/baza-jst/843, Samorzad-terytorialny-w-Polsce.html.

19. Smite, D., Moe, N. B. An ISO 9001: 2000 Certificate and Quality Awards from Outside - What's Inside? - A Case Study. Product-Focused Software Process Improvement, 2006, Vol. 4034, p. 208-221.

20. Thijs, N., Staes, P. From Self-Assessment to External Feedback. Eipascope, 2010, Vol. 1, p. 9-14.

21. Urbaniak, B., Bohdziewicz, P. Zdiagnozowanie potencjału administracji samorzadowej, ocena potrzeb szkoleniowych kadr urzędów administracji samorzadowej oraz przygotowanie profili kompetencyjnych kadr urzędów administracji samorzadowej" (raport końcowy). ASM Centrum Badan i Analiz Rynku, 2009. Available at: file://C:/Users/jurgita/Downloads/Raport_koncowy.pdf [2015-02-04].

\section{Urszula Kobylińska}

\section{Europos Sajungos parama gerinant valdymo sistemų kokybę administracinėse institucijose Lenkijoje}

Anotacija

Daugelyje Europos ir viso pasaulio šalių valdymas viešajame sektoriuje per pastaruosius keletą metų radikaliai pasikeitè. Šalių administracinė patirtis rodo, kad viešosios organizacijos šioje srityje ženkliai ịtakoja ekonomikas, perimdamos vis daugiau atsakomybių, sprendžiant sudètingas socialines ekonomines problemas. Tačiau siekiant, kad viešosios ịstagos veiktų efektyviai ir atitiktų socialinius lūkesčius, būtina realizuoti valdymo priemones ir ypatingai kokybès standartus. Tinkamų sprendimų kokybės valdymo srityje rezultatas - bendrų standartų sukūrimas, efektyvesnis išteklių naudojimas ir didesnis piliečių pasitenkinimas viešųjų institucijų darbu.

Kokybės valdymo sistemos Lenkijos viešojo administravimo įstaigose yra tapę standartu. Populiariausia naudojama priemonè - ISO 9001. Daugelis institicijų gerina savo paslaugų kokybę finansuodamos šị projektą Europos Sajungos fondų lěšomis. Šiame straipsnyje analizuojamas kokybès valdymo priemonių realizavimo efektyvumas, tinkamumas ir tvarumas Lenkijos vietos savivaldos administraciniuose vienetuose. 
Urszula Kobylińska is an Assistant Professor in the Department of Organization and Management at the Management Faculty of Bialystok University of Technology in Poland. She holds a PhD in Management.

E-mail.: u.kobylinska@pb.edu.pl.

Urszula Kobylińska yra Balstogès universiteto, vadybos fakulteto, organizacijų ir vadybos katedros Lenkojoje docentè, turinti vadybos daktaro laipsni.

E.paštas: u.kobylinska@pb.edu.pl.

Straipsnis įteiktas redakcijai 2015 m. spalio mèn.; recenzuotas; parengtas spaudai $2016 \mathrm{~m}$. vasario mèn. 